\title{
Torun Bakım Faaliyetinin Bakım Sağlayıcı Büyükannelerin Sağlık Durumları Üzerindeki Etkisi
}

\author{
The Influence of Grandchild Care Activity on the Care Provider, on the \\ Grandmothers' Health
}

\section{Sinem Burcu UĞUR*}

$\ddot{O}_{z}$ : Aile içinde yaşlılar için en yaygın sosyal rollerden biri olan büyük ebeveynlik, torunun dünyaya gelmesiyle kazanılan sosyal bir statüdür. Büyük ebeveynler aile içinde genel olarak ailenin devamlılığının sembolü, aile tarihçisi, danışman, rol model, besleyici, aile bekçisi, değer aktarımcısı, ebeveyn ile torun arasındaki hakem ve kişiliğin inşasında katkı sağlayıcı birey olarak konumlanırlar. Ancak 1970’lerden itibaren artan boşanma oranları, tek ebeveynli aile görünümleri ve kadın istihdamı gibi dönüşümler, büyük ebeveynliği giderek çocuk bakım sorumluluğunu içeren bir rol haline dönüștürmektedir. Bakım ihtiyacına cevap vermek yoluyla tekrar verimli üyeler haline gelmek, torun bakım faaliyetini içeren büyük ebeveynliğin mutluluk çağrışımları olan bir rol olduğuna işaret etmektedir. Diğer yandan bu rol, büyük ebeveynler için pek çok yükümlülüğ̈̈ de beraberinde getirmektedir. Üstelik büyük ebeveynlik yaşlllıkla bağlantılı bir kavramdır ve bu durum, kişinin kronolojik yaşı veya dinçliği, canlılığı ne olursa olsun strese girmesine neden olabilmektedir. Buradan hareketle bu çalışmada, torun bakım sorumluluğunu üstlenen büyük ebeveynlerin sağlık durumlarının bakım sürecinden nasıl etkilendiği anlaşılmaya çalışılııştır. Çaıışmada kullanılan veriler, Antalya İlinde yaşayan ve torunlarına bakım sağlayan büyükannelerle yapılan derinlemesine görüşmelerden elde edilmiştir. Yapplan görüşmeler çözümlendiğinde daha çok anne ve aile koruyucu olarak konumlanan büyükanneler için bakım sürecinin psikolojik doyum ile ilişkili olabildiği gibi, zorlayıcı bir sorumluluğa da dönüşebildiği anlaşılmıştır.

Anahtar sözcükler: Büyük Ebeveynlik Modelleri, Değişen Aile İçi İlişkiler, Çocuk Bakımı, Yaşam Doyumu

\begin{abstract}
Grandparenting, one of the most common social roles for the elderly in the family, is a social status acquired when the grandchild comes into the world. Within the family, grandparents are generally positioned as the symbol of the continuity of the family, the family historian, the consultant, the role model, the nurturer, the family watchdog, the value transporter, the referee between parent and grandchild and the contributing individuals to the formation of family members' personality. But changes since the 1970 's, such as increased divorce rates, the appearance of single-parent families and female employment have transformed grandparenting into a role that includes child-care responsibilities. By responding to the need for care, becoming a productive member again indicates that grandparenting involving care of grandchildren is a role that has connotations of happiness. On the other hand, this role also brings many obligations for grandparents. Moreover, grandparenting is a concept related to old age and this situation can lead the person to experience stress regardless of the person's age, vigour and vitality. From this point of view, in this study an attempt was made to try and understand how the health status of grandparents who undertake the responsibility of caring for grandchildren is affected by the maintenance process. The data used in the study was obtained from in-depth interviews with grandmothers living in Antalya and providing care to their grandchildren. From the results of these interviews it was understood that for those grandmothers who are more likely to positioned as mother and family protectors, the care process can be related to psychological satisfaction, as well as a compelling sense of responsibility.
\end{abstract}

Keywords: The Types of Grandparenting, Changing Family Relationships, Child-Care, Satisfaction with Life

\footnotetext{
* Dr., Akdeniz Üniversitesi, Edebiyat Fakültesi, Sosyoloji Bölümü, Antalya. ssinembalkan@live.com
} 
Aile; ortak soy, evlilik ya da evlat edinmeye dayalı oluşan akrabalık olarak tanımlanabilir (Macionis 2012, 462). Bireyi doğduğu andan ölümüne kadar çevreleyen, toplumun temel yap1 taşı olan aile kurumu, evrenseldir. Hemen hemen her toplumda en yakın akrabalardan oluşan en küçük birimden, kan ve evlilik bağıyla bağlanmış daha büyük gruplara kadar çeşitli boyutlarda aile türleri vardır (Haviland et al. 2008, 466). Aile kalıpları 1980'lerden bu yana belirgin biçimde değişikliğe uğrar. Azalan doğurganlığa karşıllk artan ömür, değişen evlilik modelleri, boşanmış, ayrı yaşayan veya hiç evlenmeyen bireylerin yaşadığı ve çiftlerin ikisinin birden istihdamda yer aldığı ev halklarının gittikçe artması gibi dünya çapında yaşanan dönüşümler, aile kurumunun yeni biçimler almasında etkili olur (Kemp 2007, 855).

Yaşlanan nüfus, yeni aile modellerinin görünür olmasında etkin rol oynayan demografik bir eğilimdir. Doğumla beklenen yaşam süresinin 1990'lardan itibaren hızlı bir şekilde artmasıyla birlikte (Akın 2006, 18) yaşlı insanlar, toplam nüfusun daha büyük bir parçasına dönüşür. Nüfusun yaşlanmasına sebep olan uzayan ömür, üç-dört kuşağın hayatlarının önemli bir kısmının örtüşmesine olanak tanımaktadır. Böylelikle torunlarından en azından birkaçıyla daha uzun bir ömrü paylaşabilen, onların hayatında önceki nesillere kıyasla daha aktif rol oynayabilen büyük ebeveynlerin sayısı oldukça artar (Gauthier 2002; Clarke \& Roberts 2004; Armstrong 2005; Dellmann-Jenkins et al. 2005; Bates 2009; Griggs et. al. 2010; Timonen \& Arber 2012; Margolis 2016). Bu bağlamda ömrün artması, büyük ebeveynlerin aile içindeki, özellikle de toruna ilişkin rolleri üzerinde oldukça etkili olur (Villar et al. 2010, 282). Artan yaşam süresinin yanı sıra, doğurganlık oranlarındaki azalış da büyük ebeveynler ve torunları arasındaki aile ilişkilerine yön verir. Hayatta olan her bir büyük ebeveynin daha az sayıda torun sahibi olmasına yol açan (Gauthier 2002, 297) bu dönüşümle birlikte büyük ebeveynler ve torunları arasında daha uzun ve potansiyel olarak daha güçlü bağlar kurulması olanaklı hale gelir (Armstrong 2005, 9). Söz konusu demografik dönüşümlere ek olarak iş piyasalarında artan kadın istihdamı, doğrudan büyük ebeveynlerle ilgili hale gelir ve büyük ebeveynlerin aile yaşamında oynadıkları rolü değiştirir.

"Esnek üretim" kavramıyla tanımlanan yeni üretim biçiminin ihtiyaç duyduğu yarı zamanlı ve/veya geçici, düşük ücretli personel açığını giderek kadınlar kapatır hale gelir (Sennett 2014). Bunun yanı sıra artan eğitim düzeyinin kadınların meslek edinmelerine bir firsat sunması ve yaşam maliyetinin giderek yükselmesi, orta kuşak kadınlarının iş gücüne katılımlarını bir zorunluluk haline dönüştürür. Annelerin işgücüne katılımı, halihazırda babaları istihdamda yer alan küçük çocukların bakım gereksinimlerini doğurur. Bu ihtiyaca binaen birçok büyük ebeveyn, torunlarının bakımında gittikçe daha fazla görev almaya başlar (Mehta \& Thang 2012, 12-13). Büyük ebeveynler ayrıca orta kuşaktaki boşanma, genç gebelik, eşlerden birinin ölümü veya torunun engelliliği gibi bireysel ve aile içi kriz dönemlerinde de torun bakım faaliyetinde aktif bir rol üstlenerek ebeveynler ve çocukların önemli destek kaynakları olma eğilimindedir (Bowers \& Myers 1999; Gauthier, 2002; Bates 2009; Griggs et al. 2010; Westphal et al. 2015). Öyle ki ailesel krizlerin yaşandığ durumlarda bakım ve korunmaya muhtaç çocukların bakımını üstlenmenin ötesinde zaman zaman torunları için ebeveynlik rolünü tekrar yerine getirebilmektedirler. Büyük ebeveynlerin söz konusu durumlarda torun bakımı sağlama, hatta "geç ebeveynler" olarak konumlanmalarının ardındaki temel dinamik, aile istikrarını sağlama gerekliliğidir. Ailelerde istikrarın sağlanması, toplumsal bütünlüğün sürdürülmesinin temel koşulunu oluşturması bakımından önemlidir. Üyelerin benlik bilinci, aile ve soy kimliği kazandırılmalarının yanı sıra korunma ve gerekli bakımlarının temin edilmesi, aile bütünlüğünün sağlanıp korunması açısından büyük öneme sahiptir. Aile kimliğinin kuşaklar boyunca aktarımı ve aile üyelerinin gereksinimlerinin karşılanması, yalnızca aile birliğinin devam ettiği durumlarda değil, risk altındaki aileler olgusunu yaratan ailesel krizlerin yaşandığ 1 durumlarda 
da toplumsal bütünlügün sürdürülmesi açısından elzemdir. Çoğunlukla büyük ebeveynler, söz konusu ailesel krizlerin esas mağdurları olan torunlarının bakım ve korunma ihtiyaçlarına cevap vererek toplumu bir arada tutan kurum olarak yapılanan ailenin istikrarını sürdürmeye çabalayan taraftır. Üstelik büyük ebeveynler için torunlarının bakım ve korunma gereksinimlerine cevap veren birincil kaynakları oluşturma eğilimi, giderek uluslararası bir hal almaktadır (Worrall 2009, 260-261). Bu gerçeklerden hareketle aile kurumunun zaman içinde geçirdiği dönüşümler neticesinde, günümüzde büyük ebeveynliğin çocuk bakım sorumluluğunu içeren bir rol olarak şekillenmekte olduğu ifade edilebilir. Ancak aile istikrarını ve üyelerinin güvenliği ve bakımını sağlama rolünü üstlenen büyük ebeveynlerin bu rolleri, fiziksel ve psikolojik sağl1kları için çeşitli sorunları beraberinde getirebilir. Bu bakımdan büyük ebeveynlerin bakım sürecinde sağlıkları bağlamında hangi zorluklara gögüs gerdiklerinin değerlendirilmesine ihtiyaç duyulmuştur.

Küresel düzeyde sağlık, nüfus gibi alanlarda yaşanan demografik eğilimlerin yanı sıra, iş piyasalarında artan kadın sayısı ve risk altındaki ailelerin giderek yaygınlık kazanması gibi dönüşümlerin etkisiyle 1980'lerin ortalarından itibaren büyük ebeveynler ve aile içindeki rollerine bilimsel bir ilgi uyanır (Bates 2009, 333). Çalışmalar daha çok aile yapısı, ailenin işlevi, sosyalizasyon ve değerlerin aktarımı, büyük ebeveynliğin anlamı, büyük ebeveynlerden beklentiler ve büyük ebeveyn-torun ilişkilerine odaklanır (Denham \& Smith 1989, 345-346). 80'ler sonrasında aile modellerinin belirgin çeşitliliği, araştırma ilgisini ebeveynler ve çocuklar için destek kaynaklarını oluşturan büyük ebeveynlere kaydırır. Boşanma, yeniden evlenme ve tek ebeveynli aile düzenlemelerinde yer alan ve çocuk bakımında birincil bakım sorumluluğunu üstlenen büyük ebeveynler odak noktası haline gelir. Son yıllarda dünyada, özellikle Batı toplumlarında büyük ebeveynlerin torun bakımı sağlamalarında etkili olan dinamiklerin belirlenmesi, ebeveynlik rolünü üstlenmeleriyle birlikte deneyimledikleri rol değişimi ve refah düzeylerini etkileyen stres faktörlerinin saptanması mevcut çalışmaların yoğunlaştı̆̆ 1 alanları oluşturur (Wood \& Liossis 2007, 381; Villar et al. 2010, 282). Buna karş1lık Türkiye'de yürütülen büyük ebeveynlik çalışmalarında ana eksen, yaşlılıktır. Dünya çapında deneyimlenen sosyolojik ve demografik dönüşümler neticesinde büyük ebeveynlerin aile içinde nasıl konumlandıklarına, hangi rolleri üstlendikleri ve bakım sürecinden nasıl etkilendiklerine odaklanan sınırlı sayıda araştırma yürütülmüştür. Bu bakımdan bu çalışmada, Türkiye'de büyük ebeveynlerin bakım ihtiyacıyla bağlantılı olarak aile içinde nasıl konumlandıkları, hangi rolleri üstlendikleri ve bu konumlarının sağlık durumlarını nasıl etkilediğini anlamak hedeflenmiştir.

\section{Bakımın Sağlandığı Ailevi Bağlam}

Aile yapısında değişikliklere yol açan uzun süreli kuşaksal örtüşme, aile içi krizler ve istihdamda yer alan kadın sayısındaki artış gibi daha önce tartışılan aileye ilişkin eğilimler, aile içinde çocuk bakım organizasyonunu da etkiler. Daha da özel olarak, bu dönüşümler neticesinde büyük ebeveynlerin çocuk bakımı faaliyetine ilişkin tutumlarına bağlı olarak farklı büyük ebeveynlik modelleri ortaya çıkar. Dünya çapında büyük ebeveynler sağladıkları bakımın niteliğine bağlı olarak temelde üç farklı büyük ebeveynlik biçimi sergiler: çocuk koruyucu, aile ve anne koruyucu büyük ebeveynlik.

Çocuk koruyucu veya koruyucu büyük ebeveynler, ebeveynlerin ebeveynlik rollerini yerine getirmekte başarısız oldukları ailelerde torunlarının birincil bakımını üstlenen büyük ebeveynlere işaret eder (Villar et al. 2010, 282). Genellikle orta kuşağın hiç olmadığı ya da çoğu zaman bulunmadıkları atlanmış nesil hanelerde (skipped generation household) yaşayan ve torunlarının birincil bakıcıları konumundaki bu büyük ebeveynler, çoğunlukla torunlarına bir tercih sonucu değil, aile krizlerinin bir sonucu olarak bakım sağlar (Cox 2008, 466). Koruyucu (custodial) 
büyük ebeveynlerin sayısını giderek artıran bu aile krizleri ebeveynlerin madde bağımlılığı, kronik fiziksel veya zihinsel hastalıkları, ölüm, tutukluluk durumları olarak belirtilir. Bu etmenlere ek olarak HIV/AIDS, artan boşanmalar, sık eş değiştirme, çocuk istismarı, iki ebeveynin de çalışması gibi nedenler de çocukların büyük ebeveynlerinin başı çektiği hane halklarında yaşama olasılığını artıran birleşimlerdir (Richards \& Harris 2001; Goodman \& Silverstein 2001; Williams 2011; Choi et al. 2016). Giderek yaygınlık kazanmakta olan atlanan nesil haneler, genel olarak ebeveynlerin ebeveynlik rollerine ilişkin yetersizliklerinden ya da ölümlerinden kaynaklanmakta ve çoğu durumda büyük ebeveynleri torunları için ebeveynlik rolünü üstlenme zorunluluğuyla karşı karşıya bırakmaktadır.

Büyük ebeveynlerin aile içinde bakıma ilişkin üstlendikleri yaygın rollerden bir diğeri, aile koruyucu büyük ebeveynlik rolüdür. Birlikte ikamet etmedikleri torunlarının ani ve görece kısa süreli ortaya çıkan bakım ihtiyacına cevap veren, torunlarıyla düzenli ya da zaman zaman temas kuran büyük ebeveynler, aile koruyucular olarak konumlanmaktadır. Aile koruyucu büyük ebeveynler daha çok ebeveynler için doğum izninin uzun olduğu, kamu çocuk bakım hizmetlerinin erişilebilir ve oldukça uygun olduğu ülkelerde orta kuşak için yedek destek niteliğinde bakım sağlamaktadırlar (Gauthier 2002; Danielsbacka et al. 2015). Ancak resmi çocuk bakım uygulamalarının yetersiz kaldığ 1 ve tüm ihtiyaç sahipleri için ulaşılabilir bakım uygulamalarının bulunmadığı, erişilemez olduğu ülkelerde büyük ebeveynler çoğunluk ailelerin bakım ihtiyacına cevap verebilen yegâne kaynakları oluşturmaktadırlar. Küçük çocuklu ailelerin çeşitli gerekçelerle resmi çocuk bakım hizmetinden yararlanamadığı durumlarda büyük ebeveynler çoğunlukla torunlarının tam zamanlı ve kapsamlı bakım sorumluluğunu üstlenmektedirler. Böylece babaların yanı sıra annelerin de işgücünde aktif olarak yer alabilmelerine firsat yaratarak anne koruyucuları olarak işlev görmüş olurlar. Ayrıca bazı durumlarda büyük ebeveynler, resmi çocuk bakımının tamamlayıcıları olarak da bakım faaliyetine dâhil olup annelerin işgücüne katılmalarını ve daha uzun saatler çalışabilmelerini sağlayabilmekte ve böylelikle eş zamanlı olarak aile ve anne koruyucu olarak konumlanabilmektedirler (Herlofson \& Hagestad 2012, 42-42). Büyük ebeveynliğin bakım niteliğine bağlı olarak temelde üç farklı biçimde görünür olması, bu rolün genellikle aile biriminin ihtiyaçları tarafından belirlenmesinden kaynaklanmaktadır. Ailenin değişen ihtiyaçlarına ilişkin bakımın hangi bağlamda sağlandığı ise torunlarının bakım gereksinimlerine cevap veren büyük ebeveynlerin fiziksel ve ruhsal refahları üzerinde farklı etkiler yaratmaktadır.

\section{Bakımın Büyük Ebeveynlerin Sağlıkları Üzerindeki Etkisi}

Torunun doğmasıyla birlikte kazanılan büyük ebeveyn kimliği ve bu yeni kimliğin getirdiği rollere katılım, büyük ebeveynlerin moralleri ve refahları için faydalı olabilmektedir. Torun bakımını da içeren büyük ebeveynlik rolü, büyük ebeveynler için kültürel ve geleneksel değerleri yeni kuşaklara aktarmanın aracı olabilmektedir. Bunun yanı sıra büyük ebeveynler söz konusu rolleri aracılığıyla ailenin yardım ihtiyacına cevap verme ve bir çocuğun yetiştirilmesine katkıda bulunma firsatı da elde edebilmekte, böylelikle sosyal ve psikolojik açıdan tatmin yaşayabilmektedir (Werner et al. 2007; Barnett et al. 2012; Doley et al. 2015). Torun bakım1 yoluyla sosyal yaşama aktif katılım şansını yakalayabilen ve aile ile toplum içinde verimli üyeler olarak konumlanabilen (Breheny et al. 2013, 175) büyük ebeveynler, bu sayede yüksek bir amaç duygusu, koşulsuz sevgi, yaşamdan haz duyma ve sosyal çevrelerinden değer görme firsatı elde edebilmektedir (Dellmann-Jenkins et al. 2005, 37). Ancak büyük ebeveynlere torun bakımı sağlama kaynaklı yaşam doyumu firsatı sunan büyük ebeveynlik, salt olumlu sonuçlar doğuran bir rol değildir. Torunlarını yetiştiren büyük ebeveynlerin ayrıca yaşam koşulları yoksullaşabilmekte, aile ve sosyal çevreleriyle ilişkileri bozulabilmektedir. Bunlara ek olarak 
torun bakım faaliyetine dâhil olan büyük ebeveynlerin sağlıklarını tehdit eden bir dizi zorlukla da karşılaşma olasılıkları yüksektir. Özellikle torunlarının tam zamanlı bakım faaliyetini üstlenen büyük ebeveynlerin sağladıkları kapsamlı destek, kendilerini çok çeşitli fiziksel rahatsızlıklar ve genellikle daha kötü sağlık koşulları tehlikesiyle karşı karşıya bırakır (Hayslip \& Goodman 2008; Bundy-Fazioli et al. 2013; Breheny et al. 2013). Gatz ve arkadaşları (1990) bakım faaliyetinin büyük ebeveynler üzerindeki etkisinin nasıl olacağında belirleyici olan etmenlerden birinin, bakım verme gereksinimini yaratan koşullar olduğuna dikkat çeker. Çocuğun ebeveynlerinin tam zamanlı istihdamı, orta kuşaktaki boşanma deneyimi ya da ailenin günlük çocuk bakım merkezlerinden faydalanma durumu, büyük ebeveynlerin torunlarının bakımlarına ilişkin tutumlarına yön vermektedir. Aile düzenlemeleriyle bağlantılı olarak büyük ebeveynler farklı nitelik ve yoğunlukta çocuk bakımı sağlamakta ve ailenin ihtiyaçlarına cevaben anne, aile veya çocuk koruyucu rollerini üstlenmektedir. Aile içinde nasıl konumland1ğına bağlı olarak farklı nitelik ve yoğunlukta bakım sunan büyük ebeveynler için bu durum, stresin görünürlügü ve şiddetini de etkiler (akt. Bowers \& Myers 1999, 304). Aile içinde anne ya da aile koruyucular olarak konumlanan büyük ebeveynler için bu rolleri daha çok iyi sağlık koşulları, sağlıklı davranışlar ve genel yaşam doyumu gibi olumlu sonuçlar doğuran bir deneyimdir. Diğer yandan çocuk koruyucu büyük ebeveynlik rolü yoğun nitelikte bir bakımı gerektirdiği için daha çok olumsuz sonuçlar ile ilişkilendirilmiştir. Aşırı rol yüklenmesi ve/veya rol karışıklığı, evlilik çatışması ve yaşam bozuklukları deneyimleme riskinin artması, bakıma muhtaç torunlar ve torunların biyolojik ebeveynleriyle çatışmalı ilişkilerin daha olası hale gelmesi büyük ebeveynlerin yüksek seviyede stres, kayg1 ve depresyon deneyimlemelerine yol açmaktadır. Ayrıca, torunlarının birincil bakımını üstlenen büyük ebeveynler, bakım faaliyetini resmi çocuk bakım kurumlarının desteği olmaksızın sürdürdüklerinde daha düşük yaşamsal tatmine karşıllk depresyona daha meyilli olabilmektedirler (Hayslip \& Goodman 2008; BundyFazioli et al. 2013; Breheny et al. 2013; Doley et al. 2015).

Çocuk koruyucu, anne koruyucu ve aile koruyucu olarak adlandırılan temel büyük ebeveynlik rolünden hangisinin yürütüldüğüne bağlı olarak büyük ebeveynlerin olumlu- olumsuz kazanımları değişmektedir. Ayrıca büyük ebeveynliğin ne zaman gerçekleştiği de deneyimlerinin çeşitli olmasında etkilidir. Gerçekleştirilen bakımın niteliği ve süresiyle birlikte, büyük ebeveynlerin hangi yaşta ve yaşamlarının hangi dönemlerinde oldukları, fiziksel ve psikolojik durumlarını olumlu ya da olumsuz yönde etkileyebilmektedir. Bir çocuğun bakımının fiziksel taleplerini karşılamada yetersiz olma ve zamana ayak uydurabilmeye yönelik endişenin yanı sıra ilerlemiş yaşın getirdiği fiziksel ve ruhsal yorgunluk, büyük ebeveynlerin stres altına girmesine neden olmaktadır (Worrall 2007, 128). Üstelik büyük ebeveynler, torunları için tek destek kaynağı olarak aldıkları büyük sorumluluğu layığınca yerine getirebilme düşüncesiyle kendi ihtiyaç ve hastalıklarını, duygusal yıpranmalarını görmezden gelme, çevreye hissettirmeme eğilimi sergilemektedirler. Bu durum tam zamanlı bakım sorumluluğunu üstlenen büyük ebeveynleri daha büyük stres altına sokmakta ve çocuklara bakan diğer gruplara kıyasla hipertansiyon, artrit ve fiziksel yorgunluk sergileme olasılıklarını artırmaktadır (Bowers \& Myers 1999; Hayslip \& Goodman 2008; Bundy-Fazioli et al. 2013; Doley et al. 2015). Bunların yanı sıra çocuğun tüm sorumluluğunu üstlenen vasi büyük ebeveynler, ilerlemiş yaşlarının ölümü daha olası hale getirmesi nedeniyle torunlarını yalnız bırakma endişesini de taşımaktadırlar (Worrall 2007, 128; Erbert \& Aleman 2008, 683). Sonuç olarak, bir çocuğun bakımını hem de kendi kuşaklarınınkinden oldukça farklılık gösteren çağın getirdiği yeniliklere uygun olarak sağlamak, büyük ebeveynlerin psikolojik ve duygusal açıdan dayanıklı olmasını gerektirmektedir. Ancak ilerleyen yaş ve sağlık sorunları, büyük ebeveynlerin hem ruhsal hem fiziksel mücadelesine ket vurabilmektedir. Özellikle torunlarının tüm sorumluluğunu üstlenen koruyucu 
büyük ebeveynler için bu durum, yüksek kaygı düzeyi ile ilişkilidir. Farklı araştırmalar tarafından ortaya konan bu bulgular, bakıcı büyük ebeveynlerin bakım stresine ilişkin deneyimlerinde birbirinden farklı birçok faktörün rol oynadığına işaret etmektedir. Bu bağlamda, bu çalışmanın temel problemi, büyük ebeveynlik deneyiminin büyük ebeveynlerin hayatlarını iki yönlü olarak büyük bir değişime uğrattı̆̆ı; bakım sağlayıcı birey olarak aile ve toplum içinde verimli üyeler haline gelen büyük ebeveynler için bu rolün psikolojik tatmin aracı olabildiği gibi, kötü sağlık ile bağdaşlaştırılabilen bir rol de olduğu argümanına dayanmaktadır. Büyük ebeveynlik deneyiminin farklı etkilere sahip olmasının çocuk bakım koşullarına ilişkin ailevi bağlamdan kaynaklandığı varsayımı, farklı ailevi bağlamlarda değişik yoğunluk ve niteliklerde sağlanan bakımın büyük ebeveynlerin hayatlarını nasıl etkilediğini incelemeyi gerektirmiştir. Ayrıca, büyük ebeveynlerin yaş özellikleri de torun bakımına dahil olma derecelerini ve bakım sürecinde üstlendikleri rolleri çeşitlendiren bir unsur olarak değerlendirilmiştir.

\section{Araştırma Tasarımı}

Küresel düzeyde yaşanan hızlı ve çarpıcı dönüşümler neticesinde aile içinde çocuk koruyucu, aile koruyucu ve anne koruyucular olarak konumlanan büyük ebeveynlerin söz konusu rollerinin sağlıklarına ilişkin deneyimlerini nasıl çeşitlendirdiğinin anlaşılması için sınırlı sayıda katılımcının bakım faaliyetine ilişkin öznel deneyimlerine odaklanılmıştır. Bu bakımdan oluşturulacak bilginin ayrıntıl, derinlemesine olması, büyük ebeveynlerin kendi deneyimlerini ve bu deneyimleri nasıl algılayıp yorumladıklarını yansıtabilmek düşüncesinden hareketle niteliksel yöntem tercih edilmiştir.

Araştırmada, araştırma amacına uygun bir örneklemin belirlenmesine dikkat edilmiştir. Araştırmanın temel öğeleri hakkında bilgi ve deneyim sahibi olan, yaşantılarından bu öğeler hakkında bilgi oluşturmanın mümkün olduğu kişilerin örnekleme dâhil edilmesine hassasiyet gösterilmiştir. Araştırmaya katılacak büyük ebeveynlerin seçimi olasılıklı olmayan örnekleme türlerinden biri olan Kartopu Örnekleme tekniği ile sağlanmıştır. Bu teknikte kaynak kişilerden yola çıkılarak diğer kişilere ulaşıldığından bir yönlenme ve aynı özellikleri barındıran belli grup ya da kişilere ulaşma riski mevcut olduğu (Kümbetoğlu 2017, 99-100) için bu riski görece ortadan kaldırabilmek amacıyla birkaç kartopu oluşturulmasına dikkat edilmiştir. Araştırma örnekleminin seçiminde temel kriter, büyük ebeveynlerin torunlarının bakım ihtiyacına cevap verebilmeleri ve bakım sürecine çeşitli yoğunluklarda dahil olmaları olarak belirlenmiştir. Antalya ilinde, torun bakımına ilişkin aile içinde anne, aile ya da çocuk koruyucu olarak konumlanan 50 büyükanne ile görüşme gerçekleştirilmiştir.

\section{Alandan Elde Edilen Verilerin Sunuluşu}

Büyük ebeveynler aile biriminin ihtiyaçlarıyla bağlantılı olarak torun bakım sürecine farklı yoğunlukta dâhil olmakta, bu durum fiziksel ve ruhsal refahlarına ilişkin deneyimlerini farklılaştırmaktadır. Büyük ebeveynlik, torunların birincil bakımı üstlenen ya da çocuk bakımını tamamlayıcı bir nitelikte sağlayan büyük ebeveynler için farklı kazanımları olan bir roldür. İyi sağlık koşulları, sağlıklı davranışlar ve genel yaşam doyumu ile ilişkilendirilebilen bu rol aynı zamanda depresyon, kötü sağlık ve kötü refah riski de taşımaktadır. Bu rolün büyük ebeveynler üzerindeki etkisinde belirleyici olan esas unsur, bakımın nitelik ve yoğunluğudur. Ebeveynsel bakıma destek niteliğinde, tamamlayıcı nitelikte bakım sunan büyük ebeveynler, büyük ebeveynlik rollerini ödüllendirici bir deneyim olarak algılama eğilimi sergilemektedir. Diğer yandan bakım faaliyetinin yoğun ve düzenli bir nitelik kazandığı durumlarda büyük ebeveynlik, yaşam memnuniyetini düşüren bir yüke dönüşebilmektedir. $\mathrm{Bu}$ gerçek, büyükannelerin sağladığı bakımın kapsam ve yoğunluğu ile yürüttükleri bakım faaliyetiyle bağlantılı olarak aile 
içinde nasıl konumlandıklarını anlamayı gerektirmiştir. Dünyada, özellikle de Batı toplumlarında büyük ebeveynlerin aile içinde sergiledikleri temel büyük ebeveynlik modelleriyle paralel biçimde, büyükanneler sağladıkları bakım doğrultusunda aile içinde çocuk koruyucu, aile koruyucu ve anne koruyucu olmak üzere üç farklı şekilde konumlanmıştır. Torunlarının bakım faaliyetini üstlenen büyükannelerden hemen hemen yarısı (28 büyükanne) sağladığı düzenli bakım neticesinde anne koruyucular olarak konumlanırken, söz konusu kadınlardan bazıları (8 büyükanne) başka torunları için eş zamanlı olarak yardımcı bakım sağlamaları nedeniyle aynı zamanda aile koruyucu büyükanneliği sürdürmektedir. Torunlarının birincil bakımını üstlenerek çocuk koruyucular olarak konumlanan büyükannelerin sayısı, 6' dır. Tam zamanlı bakımı sürdüren iki büyükanne ayrıca diğer torunları ile ebeveynlerinin hayatlarında aile koruyucu olarak konumlanmıştır. Üstlendikleri yardımcı bakım sorumluluğu bağlamında aile koruyucular olarak konumlanan 26 büyükannenin büyük bir kısmı (10 büyükanne) aynı zamanda anne ya da çocuk koruyucudur.

Bakımın sağlandığı ailevi bağlamın yanı sıra, büyük ebeveynlerin yaşları da bakıma ilişkin algılamalarına yön vermektedir. Kendi çocuk yetiştirdikleri dönemden oldukça farklı koşullarda, üstelik de artan yaşları ve bağlantılı olarak bozulan sağlıkları nedeniyle fiziksel olarak formda olmadıkları bir dönemde bir çocuğun yetiştirilmesi sorumluluğunu üstlenmek, büyük ebeveynlerin ruhsal refahları üzerinde olumsuz bir etki yaratabilmektedir. Özellikle daha yoğun bir nitelikte bakım sağlayan koruyucu büyük ebeveynlerin sağlıkları bu durumdan daha olumsuz etkilenebilmektedir. Araştırmaya katılan büyükannelerin yaş dağılımları incelendiğinde, büyük çoğunluğunun (44 büyükanne) Dünya Sağl1k Örgütünün "Dünya Sağllk İstatistikleri 2016" raporunda (Theraphysio 2017, 8) yer alan güncellemiş yaş dağılımları çerçevesinde, genç yaşı temsil eden 18-65 yaş grubunda yer aldığı anlaşılmıştır. Görüşülen büyükannelerin geri kalanlarının orta yaşı temsil eden 66-79 yaş aralığında yer aldığı görülmüştür. Yaşlı olarak sınıflanan grupta ise herhangi bir katılımcı bulunmamaktadır. Bakıcı büyükannelerin büyük çoğunluğu (27 büyükanne) 45-59 yaş grubunda yer alırken; yaklaşık yarısı (22 büyükanne) 60-74 yaş aral1ğında yer almaktadır. Bakım sağlayıcı büyükannelerin yaş ortalaması 59,16 olup, araştırma örneklemini orta yaşlılar oluşturmuştur.

Büyükannelerin hangi aile düzenlemelerinde bakım verdikleri ve bakım sürecindeki yaşları anlaşıldıktan sonra, çocuk bakımına dâhil olma dereceleriyle bağlantılı deneyimlerinin karşılaştırılabilmesi açısından torun bakımının sağlıklarını nasıl etkilediğine ilişkin algılamaları, yaşlarıyla bağlantılı olarak bakımı yorucu bulup bulmadıkları ve çocukların ihtiyaçlarına cevap veriyor olmanın yarattığı his değerlendirilmiştir.

\section{Çocuk Koruyucu Büyükanneler Açısından}

Torunlarının koruyucu büyük ebeveynliğini üstlenen büyükanneler, sağlıklarına dair hem olumlu hem de olumsuz algılamalara sahiptir. Tam zamanlı bakım sağlayıcı konumundaki büyükannelerin çoğu torunları için daha aktif ve dinamik olmak durumunda kaldıklarını belirtmiş, büyükannelerden biri torunların ihtiyaç ve beklentilerinin bu durumun ardındaki dinamik olduğunu şu şekilde ifade etmiş̧ir;

Olumlu yönde etkiliyor; çünkü kendini düşünmüyorsun. O zaman daha enerjik olmak zorundasin daha hareketli oluyorsun. Çocuklar için daha sağllklı yemekler yapmak için uğraşıyorsun işte mesela dün bir sürü meyve aldım geldim komşu göndermişti onlara meyve suları hazırladım klşlık, günüm öyle geçti dün. Ben de onları yiyorum (G7, çocuk koruyucu). 
Diğer yandan büyükannelerin çoğu, dâhil oldukları büyükannelik modelini yorucu bir rol olarak tanımlamıştır. Aralarında çok yaş farkı bulunmayan 2 çocuğun aynı anda tüm sorumluluğunun üstlenilmesi, çocuk koruyucu bakımın diğer torunlarına sağlanan başka nitelikte bakımla birlikte sürdürülmesi ve ilerleyen yaş, bazı büyükannelerin bakımı yorucu bir deneyim olarak değerlendirilmelerinde etkili olmuştur. Torunlarının tüm bakım sorumluluğunu üstlenmiş olmalarına rağmen, diğer büyükannelerin tam zamanlı bakımı yorucu bir görev olarak tanımlamamaları torunların yaşıyla açıklanabilir. Kendi temel ihtiyaçlarını karşılayabilecek yaşa gelmiş torunlarının birincil bakımını üstlenen büyükanneler torun bakımını yorucu olarak değerlendirmemişlerdir. Büyükannelerin uykusuz kalmaya ilişkin deneyimleri de benzer biçimde yaşa bağlantılı olarak değişkenlik gösterir. Yaşça büyük torunlarına bakmakta olan büyükanneler uykusuz kalmadıklarını ifade ederken; yaşça küçük torunları olan büyükanneler için ise torun bakımı uyku düzenlerini bozan bir deneyim olmuştur. Bazı büyükannelerin bel ve bacak ağrıları biçiminde deneyimledikleri fiziksel sağlıksızlık halinin de yaşa bağlı olarak geliştiği anlaşılmıştır. İlerleyen yaş, fiziksel sağlık üzerinde olumsuz etkiler yaratabildiği gibi, büyükannelerden bir kısmının psikolojik sağlıklarına da zarar vermiştir. Bir büyükanne ilerleyen yaşının sağlığını zayıflatması ve ölümü daha olası hale getirmesine ilişkin kaygılarını şu şekilde ortaya koymuştur;

Bir duam var Allah'a doğru konuşayım, Allah'ım ya Rabbim şu çocuklar 12 yaşa gelene, şöyle başlarını kurtarana kadar Allah bana bir uzun ömür versin, şu torunlartn bir eli ekmeğe yetsin diyorum, bunu da diyorum demedim değil. Ben hiç kimseye inanamıyorum yani kızım şöyle eliyle de tutsa çocukları biraz ağlatsa kızımı (annelerini) öldüresim geliyor, inanmiyorum hiç inanmiyorum doğru konuşayım (G3, çocuk koruyucu).

Yukarıda da örneklendiği üzere artan yaşla bağlantılı olarak sıklaşan sağlık sorunları büyükanneleri torunlarının geleceği için endişelendirir hale getirmiştir. Torunlarının kendilerinden sonra ihtiyaç duyduğu bakımı alamayacakları endişesi, büyükanneleri yüksek stres seviyesiyle karşı karşıya getirmektedir. Araştırmada oluşturulan bu veri, Williamson ve meslektaşlarının $(2003,27)$ ve Worrall'ın $(2007,128)$ çocuk koruyucu büyük ebeveynlerin sağlık problemleri nedeniyle gelecekte torunlarına yeterli bakımı sağlayamayacakları ya da ölmeleri durumunda arkalarında torunlarının bakımını sağlayabilecek birini bırakamayacakları kaygısını taşıdıklarına ilişkin görüşleriyle paralellik göstermektedir.

Işste bu şekilde olmasa iyiydi de hani böyle eşiyle problem olunca işte biraz insan üzülüyor. Illla ki çocuğuna yardım etmek zorundayız, gücüme gitmiyor, o da senin bir parçan artık ama keşke böyle olmasaydı ben gene yardım etseydim (G8, çocuk koruyucu).

Hayatım torunla daha iyi geçmişti şöyle iyi geçmişti tabii ki annesiz olduğu için çok ağladım, çok üzüldüm, depresyona girdim çocuğun annesi yok diye ondan sonra insanoğlu ona da allşlyor... beni çocuk hiç yormadı beni ne yordu, annesi gitti ya o zaman işte artık o zaman çok ağladım, çok kendimi hirpaladım. Bu klz çocuğunu tut elinden götür okula ben senden hiçbir şey istemiyorum yeter ki sen bu uşağı böyle bırakma; onu etmedi ona çok üzüldüm yani çok üzüldüm o zaman çok şey oldum ama çocuğa yansitmadım gizli gizli ă̆llyordum... Onla ilişkilerim çok iyiydi, o da tabii üzüntüsüyle depresyona o da girdi annesi böyle olduğu için depresyona girdi. Doktora götürdüm hap 
kullanıyordu sinirliydi o zamanlar, şimdi hapı kullanmayı bıraktı iyi şükür hamdolsun (G22, çocuk ve aile koruyucu).

Yukarıdaki anlatılara yansıdığ gibi, büyükannelerin bazıları için torun bakımının sağlıksız ruh hali ile ilişkili olmasının ardındaki dinamik, orta kuşakta yaşanan, büyük ebeveyn müdahalesini gerektiren aile krizleridir. Büyükanneler hem çocuklarının torun bakım ihtiyacına yol açan ailevi krizleri yaşamalarından mutsuzluk duymakta, hem de bu krizlerin esas mağduru olan torunlarının bu süreçte hayal kırıklığı ve kırgınlık yaşamalarından kaygılanmaktadırlar. Ayrıca, ailevi krizleri deneyimleyen bazı torunların yaşadıkları ihmali duygusal problemler göstermek suretiyle yansıtmaları da büyükanneleri strese ve zora sokmaktadır. Buna dayanarak, büyükannelerin psikolojik sağlıklarının bozulmasının torun bakımının birebir sonucu olmadığı, büyük ebeveynlerin bakım sağlamalarına yol açan ailevi koşulların bu durumun esas kaynağı olduğu ifade edilebilir. Bakım ihtiyacını yaratan farklı koşulların büyükannelerin psikolojik sağlıkları üzerinde benzer bir etki yaratmayabileceği belirtilebilir. Çalışmanın bu verisi, Bowers ve Myers'in $(1999,304)$ büyük ebeveynlerin normal olmayan bir yaşam düzenlemesi içinde torunlarına bakmalarını gerektiren aile travmalarının stres düzeylerini artırdığına ilişkin görüşlerini desteklemektedir.

Bakımın sağlandığı ailevi bağlamın yanı sıra, aşağıdaki anlatıda da vurgulandığı gibi, bakım sağlanan torunların cinsiyetleri de büyükannelerin stres seviyelerine etki eden bir unsur olarak işlev görmüştür. Torun bakımını yüksek kaygı düzeyi ile ilişkilendiren büyükannelerin ikisi de kız torunlara sahiplerdir ve orta kuşak desteği olmaksızın güvenli bulmadıkları bir çevrede kız çocuk yetiştirmekten kaygılandıklarını aktarmışlardır.

Antalya gibi yerde babasız çocuk yetiştiriyorum, Antalya gibi yerde babasız klz çocuk. Daha ben çocukları bu sene saldım dışarıya komşunun kizı var ü̧̧ yaşında sokakta geziyor çocuk, ben daha bu sene çıkardım. Zor, kolay değil Antalya gibi yerde babasız kız çocuk büyütmek ne demek ya (G3, çocuk koruyucu).

Çocuk koruyucu büyükannelik rolünü üstlenmek, büyükannelerin sağlıkları üzerinde hem olumlu hem de olumsuz etkiler yaratır. Yaş, çocuk sayısı, cinsiyet gibi faktörlere bağlı olarak büyükannelerin çocuk bakımına ilişkin deneyimleri değişkenlik gösterse de hepsi, torunlarına sağladıkları bakımı kendi çocuklarının ihtiyaçlarına cevap verebilmenin aracı olarak değerlendirmektedir.

Bana göre güzel bir şey. Ben çalışan birisi olmadı̆̆ım için en azından çocuklarım baklciya para vermiyor, baklciya verecekleri paralarla kendi ihtiyaçlarını gideriyor. Ben o yönden çocuklarıma yardımcı olduğumu düşünüyorum, öyle yardımcı olduğumu düşünüyorum. Başka bir şey yapamayacağıma göre bir maaşım yok, herhangi bir gelirim yok onunla da çocuklarıma yardımcı olduğumu düşünüyorum (G49, çocuk ve aile koruyucu).

Torunlarına bakmak suretiyle kendi çocuklarına yardımcı olabildiklerini düşünen büyükannelerden birinin yukarıdaki anlatısında da vurgulandığı gibi, koruyucu büyükanneliği üstlenmek, büyükannelerin kendilerini mutlu ve yararlı bireyler olarak tanımlamalarının aracı olmuştur. Bu bağlamda içerdiği tüm zorluklarına rağmen, tam zamanlı bakım sürecinin çocuk koruyucu büyükannelerin psikolojileri üzerinde olumlu bir etki de yarattı̆ğ ifade edilebilir. 


\section{Anne Koruyucu Büyükanneler Açısından}

Torunlarının düzenli bakımını üstlenen büyükannelerin sağlık durumlarının bakım sürecinden nasıl etkilendiği değerlendirildiğinde, aile içinde anne koruyucular olarak konumlanan söz konusu büyükannelerin kendi sağlıklarına ilişkin daha çok olumlu algılara sahip oldukları anlaşılmıştır. Uzun süreli ve yoğun nitelikte bakım sunan bu büyükanneler torun bakım faaliyetinin zaman zaman sinir bozucu, stres ve yorgunluğa yol açan bir sorumluluğa da dönüşebildiğini vurgulamışlardır. Torunlara düzenli olarak bakım sağlamanın sağlıklarını olumlu yönde etkilediğini ifade eden büyükannelerin hepsi, torunların düzenli bakım ihtiyacının kendilerini daha enerjik, daha canlı olmaya yönlendirdiğini belirtmiş, bazı büyükanneler ayrıca bakımın psikolojik sağlık üzerindeki etkisinin de altını çizmişlerdir.

Vallahi sağlığımı aslında çok güzel etkiledi, çok iyi oldum, daha dinçleştim. Çocuğa bakınca daha iyi oldum kendime geldim. Özgüvenim geldi tekrar kendime (G39, anne koruyucu).

Daha dikkat ediyorum kendime, nezle olmamaya bile dikkat ediyorum çünkü ona da bulaşacak diye. Daha önce o kadar çok dikkatli değildim, sık sık hasta oluyordum, şimdi olmamaya çalışlyorum, olmuyorum da. Daha enerjik hissediyorum çünkü çocukla hareket içindeyim, koşturuyoruz oynuyoruz ev işini yapıyorsun ona yetişmeye çalışıyorsun mesela birçok yaşıtımın evde oturanların eklem ağrlları var, dizlerinden bilmem neden şikâyet ediyorlar, benim yok (G42, anne koruyucu).

Benim önceden belim ağrlyordu şimdi onlarl unuttum, toruna bakarken unutuyorsun onları, iyileştik bize iyi geldi. Kesinlikle daha canl, enerjik olmak zorundayı. Kendimize de daha iyi baklyoruz onun büyüdügünü görmek için. Çocuk da bizi yaşlı eğri büğrü görmesin, iyi bakıyoruz kendimize iyi bakmaya çalışıyoruz (G23, anne koruyucu).

Çok daha enerjik daha güzel, ölü de olsan ayaktasın diri de olsan ayaktasın; să̆lığımı öyle etkiliyor (G30, anne koruyucu).

Torunların günlük temel ihtiyaçlarının karşılanmasının yanı sıra, kişisel gelişimlerini destekleyecek aktivitelerin düzenli olarak gerçekleştirilmesi gerekliliği, büyükannelerin kendilerine özen göstermelerinde etkili olmuştur. Büyükanneler torunlarının istek ve ihtiyaçlarına cevap sunabilmek için sağlıklarını daha çok önemseme, kendilerini koruma eğilimi sergilerler. Torunlarının düzenli bakımlarını aksatmadan sürdürebilmek için sağlıklı olmaları gerektiğini ifade eden büyükannelerden biri yukarıdaki son anlatıda da yer verildiği üzere bu durumun gönüllü bir tercihten ziyade bir zorunluluk niteliği taşıdığını belirtmiştir.

Görüşülen anne koruyucu büyükannelerden bazıları torunlarının düzenli bakımını üstlenmenin genel sağlıkları üzerinde olumlu bir etki yaratmakla birlikte, kimi durumlarda sağlıklarını tehlikeye atabildiği üzerinde durmuştur. Düzenli bakım sorumluluğunun zaman zaman kötü sağlık ile ilişkilendirilmesinin temel sebebi, dinlenme ya da kişisel ihtiyaçlara zaman ayrılmasına fırsat vermeyecek denli yoğun nitelikte sağlanan bakımın oldukça yorucu bir faaliyet olmasıdır. Anne koruyucu büyükannelik rolü, çoğu durumda en az 2 yıl süreli olmak üzere haftanın 5 günü ortalama 12 saat gerçekleştirilmekte, bu durum da büyükannelerin yorgun hissetmelerine sebep olmaktadır. Görüşülen büyükannelerden biri düzenli bakımın neden yorucu bir deneyim olduğunu şu şekilde ifade etmiştir; 
Tabii ki yorucu oluyor, aslında öyle yorucu bir çocuk değildi benim torunum ama yine de her an her dakika onunla ilgilenmek zorundasin, bakmak zorundasın. İste yemeği, oyun oynama saati, uyku saati, her şeyini ona göre ayarllyorsun, temizliğini ona göre ayarlyyorsun. Her konuda onunla birebir ilgilenmek zorundasin (G 39).

Hemen hepsi anne koruyucu büyükanneliği yorucu bir rol olarak tanımlayan büyükannelerin artan yaşları ve bununla bağlantılı olarak hâlihazırda tam bir iyilik hali içinde bulunmuyor olmaları, enerjik ve hareketli yapıdaki torunları için yoğun, kapsamlı bir bakım sağlamaları bakımı yorucu bir deneyim olarak değerlendirilmelerinde etkili olmuştur. Ayrıca söz konusu büyükannelerin bir kısmının düzenli bakımı başka torunları için başka ailevi bağlamlarda sağladıkları bakımla eş zamanlı sürdürmeleri, yorgunluk seviyelerini artırmaktadır.

Ben biraz zorlanıyorum çünkü dizimden ameliyat oldum bir de torun çok hareketli acayip afacan çok hareketli, peşinden çok koşuyorum (G4, anne koruyucu).

Sağglığımı biraz etkiledi, çünkü ben beyin ameliyatı oldum yorulduğumda baş dönmem oluyor (G2, anne koruyucu).

Yıpranmaya başladım, gencim de yapabiliyorum. Genç olmasam yapamam (G10, anne koruyucu).

Torun bakımı sağlığımı etkiliyor, etkilemez desem yalan olur; çünkü rahatsızlı̆ım var, yoruluyorum, dizlerimden rahatsızım. Ayaklarım şişiyor sürekli koşturuyorsun, yedir altını değiştir en ufak bir şeyde ayak$\operatorname{tasin}(\mathrm{G} 21$, anne ve aile koruyucu).

Büyükannelerin yorgunluklarını artırabilen bir başka etken, uyku ihtiyacının yeterince karşılanamamasıdır. Torunlarının bakımları sırasında uykusuz kaldıklarını belirten büyükannelerin (8 büyükanne), sabah ebeveynlerin mesaisi başlamadan torunlarının bakımını üstlenmek üzere hazır bulunmak için çok erken saatlerde kalktıkları ve akşam torunlardan arta kalan zamanda ev işlerini tamamlayabilmek için geç saatlere kadar ayakta kaldıkları anlaşılmıştır. Ayrıca hemen hepsinin torunlarının 3 ve altı yaşlarda olmaları bakımından temel ihtiyaçlarının karşılanması konusunda bakım sağlayıcılarına bağımlı oldukları görülmüştür. $\mathrm{Bu}$ durumun büyükannelerin gün içinde de uyku takviyesinde bulunmalarını engelleyerek yorgunluklarını pekiştirdiği anlaşılmıştır.

Bakımın kendi günlük aktivitelerine, kişisel ihtiyaçlarına ayırabilecekleri zamanı kısıtlamalarını gerektirecek kadar yoğun olduğu durumlarda büyükanneler sadece yorgunluk gibi fiziksel olumsuzluklar deneyimlemezler. Yoğun bir bakım faaliyeti, büyükannelerin psikolojik sağlıkları üzerinde de olumsuz etkilere sahiptir. Üstelik bu kadar kapsamlı ve yoğun bakım faaliyetinin, çocuğun ebeveynleriyle devam eden gergin ilişkiler temelinde sürdürülmesi de büyükannelerin psikolojik refahlarına zarar verebilmektedir.

Küçük olduğu için çok huzursuzlanıyor bazen onu mutlu etmek için ev işini şeyi bırakıyorum, daha çok onunla oynuyorum; bir taraftan da işler kaldiğı için psikolojik olarak da yoruluyorum (G48, anne koruyucu).

Yani sürekli koşturuyor çok enerjisi yani mecburen biz de daha canlı olmak zorundayız, Ona bir şeyler yapacaksin mecburen canlyyzz... Ruh halime bağlı herhalde gelinle biraz iyi olmadı̆̆ için ona sinirleniyorum, 
o mu stres yapıyor bende acaba, vallahi öyle oluyor (G20, anne ve aile koruyucu).

Torunlarının düzenli bakımını üstlenen büyükannelerin hemen hepsi için torunlara sağlanan bakımın asıl öznesi, kendi çocuklarıdır. Büyükanneler torun bakımı yoluyla çocuklarının sıkıntı çekmemesi, yaşam koşullarını iyileştirebilmesi, özellikle de orta kuşak kadınların annelik ve istihdamı birleştirebilmelerinin aracı olmakta ve böylece çocuklarının hayatlarında verimli üyeler olarak konumlandıklarına inanmaktadırlar. Yaptıkları fedakârlıkların "yararlı olmanın verdiği doyum" biçiminde karşılık bulduğuna inanma eğilimi, büyükannelerin bakımdan duydukları tatmini artırmaktadır.

Mutluyum çünkü onlar karı koca işten geliyorlar, çocuğumuz ne oldu derdi yok, yemeklerini yiyorlar güle oynaya evlerine gidiyorlar. Onlar mutlu, ben de mutluyum. Onlar kavga etseler çocuk bakma ile ilgili olarak ne pişirdin ne ettin ne tuttun ay çocukla ilgilenmiyorsun bakmadın diye onlar kavga edince anne baba huzurlu olur mu? Ben olur muyum, olmam. Kendimi yararl hissediyorum, ben olmasam bilmem ne eder bunlar diye de düşünüyorum (G9, anne koruyucu).

Çok mutlu oldular, onlar akşam eve geldiklerinde onların yüzlerinin ifadeleri, mimikleri beni müthiş huzurlu yatırdı, çok huzurlu hissediyorum bakın hiç abartıl konuşmuyorum. Bir gün hiç unutmuyorum gelinim geldi oğlumla beraber, yemekler yapılmış mis gibi kokuyor dolabı açıyorlar dolap dolu. Kendi aralarında konuşuyorlar, bakar misın şu eve bizim evimiz alışı değil böyle şeylere diye saldırlyorlar böyle baklyorlar masa hazır dede de çok güzel salatay yapmış masaya koymuş o evin o atmosferi var ya seni nasil mutlu ediyor anlatamam sicacık bir ortam o başka bir şey (G29, anne koruyucu).

Sahadan elde edilen veriler, anne koruyucu büyükannelik rolünü üstlenmenin büyükannelerin sağlıklarını olumsuz etkilediğine işaret etse de büyükannelerin tamamı torunlarıyla vakit geçirmenin ve torunlarının sevgisinin her türlü çekilen sıkıntı ve zorluğa değdiğini vurgulamıştır. Sağlanan psikolojik doyum büyükannelerin genel refahları üzerinde olumlu bir etkiye sahiptir. Büyükanneler için, yorgunluk ve uykusuzluk yaşasalar dahi, torun sevgisi ağır basmakta, yaşadıkları yorgunluğu tatlı yorgunluk olarak tanımlama eğiliminde olan büyükanneler için düzenli bakım faaliyeti yaşamdan duyulan memnuniyetin aracı olmaktadır.

\section{Aile Koruyucu Büyükanneler Açısından}

Torunlarına yardımcı bakım sağlayan 26 büyükannenin büyük çoğunluğunun görüşmeler zarfında yardımcı bakım sağlamakta oldukları torunları için belli bir dönem düzenli bakım üstlendikleri anlaşılmıştır. Torunların artan yaşı ve yaşla bağlantılı olarak kreş, anasınıfi veya okul eğitimlerine başlamaları ve torunların annelerinin istihdamdan ayrılmaları gibi nedenler, büyükanneleri düzenli bakıcılardan tamamlayıcı bakım sağlayıcılara dönüştürmüştür. Tamamlayıcı bakımın düzenli bakımı takiben ortaya çıkması, büyükannelerin tamamlayıcı bakımı yorucu bir deneyim olarak değerlendirilmelerinde ana etken olmuştur. Daha önceleri torunlarının düzenli bakımından sorumlu olan bazı büyükannelerin ( 9 büyükanne) hiç ara vermeksizin torunlarının tamamlayıcı bakıcılarına dönüşmesi, daha az yoğun olmakla birlikte dinlenebilme firsatı bulamadan bakım sağlamaya devam etmelerine işaret etmektedir. Torunların ihtiyaçlarına cevap verme gerekliliğinden ziyade, düzenli bakımdan kaynaklanan alışkanlıktan hareketle orta kuşak kadınlarının ev içindeki görevlerini hafifletmeye yönelik çabaların büyükannelerin torun 
bakım sorumluluğunu yorgunluk ile ilişkilendirmelerinin nedeni olduğu anlatılardan yansımaktadır.

Ona bakarken hiç yorulduğumu hissetmiyorum ama sonra oturduğumda anliyorum yorulmuşum diyorum; artık bizim de yaş 50 oldu, 50 geçince. Bir de sadece torun bakarken değil başka bir şey de yaptyorsun yanında tek torun baksan belki o kadar yorulmazsin. Evde yemek yapıyorsun, bir şeylerle uğraşlyorsun, yemek yapayım onlar şunu seviyorlar diyorum, yemek yapayım çocuk şunu seviyor, bunu yapayım diye sadece çocuğa bakmakla bitmiyor (G1, anne ve aile koruyucu).

Eski anne koruyucu, yeni tamamlayıcı bakım sağlayıcılar olarak konumlanan büyükannelerin çoğunluğunun ayrıca uyku ihtiyaçlarını da yeterince karşılayamadıkları, bu durumun da yorgunluklarını pekiştiren bir unsur olduğu anlaşılmıştır. Bu bağlamda, yardımcı bakıcı konumundaki büyükannelerin yorgunluğa ve uykusuz kalmaya ilişkin deneyimlerinin düzenli bakım sağlayıcılarla benzerlik gösterdiği ifade edilebilir. Büyükannelerin ayrıca tamamlayıcı bakımı başka torunları için sağladıkları düzenli bakımla birlikte sürdürmeleri, torunların ihtiyaçlarına cevap verme gerekliliği, torunun emanet olması bakımından bakımının çok fazla sorumluluk içermesi ve ilerleyen yaşları, yardımcı bakımı yorucu bir deneyim olarak algılamalarının ardında yatan dinamikler olarak sunulmuştur.

Sağlı̆̆ımı tabi o çok etkiledi, sağlığınız bozuluyorsa çok zor oluyor; hem sorunların var sağllk sorunun ama ayağa kalkman gerekiyor çocuk senden bir şeyler bekliyor enerjik olmak zorundasın. Tamam, hakikaten çok büyük bir doping sen yalnızken daha farklı olan bir insan güç buluyorsun torun sayesinde. ...sağllk çok düşünemiyorsun kendini, düşünemiyorsun, tabii öyle oluyor. Yani yoruluyorsun sağlığın iyi olmadı̆g zamanlar bakıldığında destek bekliyorsun (G6, aile koruyucu).

Yukarıdaki anlatıda vurgulandığı gibi, yardımcı bakımın bazı büyükanneler için zaman zaman kötü sağlık koşulları ile ilişkili olmasında etkili olan bir diğer unsur, mevcut sağlık durumlarının çok iyi olmamasıdır. Genel sağlıklarının bozuk olduğu zamanlarda dahi bakım sağlamak durumunda kalmak, durumlarını ağırlaştırabilmiş ve bu bakımdan torun bakımı fiziksel sağlıklarına zarar verebilen bir deneyim olarak algılanabilmiştir. Bu bakımdan, kötüleşebilen sağlığın torun bakımının sonucu olmadığı, büyükannelerin bakımı üstlendikleri andaki sağlık durumlarının bakımın etkisinde belirleyici unsurlardan biri olduğu ifade edilebilir.

Yorgunluk, uykusuzluk ve kötüleşebilen sağlık gibi deneyimlerine rağmen, sağladıkları bakımın niteliğinin değişmesiyle birlikte aile içinde eski anne koruyucu yeni aile koruyucu olarak konumlanan büyükannelerin hepsi, kendi sağlıklarına ilişkin olumlu algılara sahiptir. Torunlarına yardımcı bakım sağlamanın sağlıklarını olumlu yönde etkilediğini ifade eden büyükannelerin hepsi, torunların bakım ihtiyacının kendilerini daha enerjik, daha canlı olmaya yönlendirdiğini belirterek torun bakımının fiziksel sağlıkları üzerindeki etkisini vurgulamışlardır. Ayrıca büyükannelerin bazıları, bakımın psikolojik sağlikları üzerindeki olumlu etkisine odaklanmıştır. Bakımın psikolojik ve fiziksel iyilik hali üzerindeki olumlu etkisi, tamamlayıcı nitelikte bakım sağlayan büyükannelerin bazılarına ait aşağıdaki anlatılardan yansımaktadır.

Sağllğımı olumlu etkiliyor. Ne bileyim çok oturup da şuram ağrıyor buram ağrlyor veya ne bileyim kontrollere gitmem gerekiyor diye düşünmüyorum, daha canll, daha enerjik oluyorum. Koşturmak zorunda kalıyor gibi oluyorsun, zorunda değil de nasıl desem çocuğa bakacaksın, 
alı̧̧veriş yapacaksın falan bunları hep dinamik olup koşturayım diyorsun koşturuyorsun (G40, aile koruyucu).

Sağlı̆̆ımı çok güzel etkiliyor, benim ömrümü uzatıyorlar, gerçekten. Onları bir gün görmeyeyim, yani onlar varken gözlerinin içine bakıyorsun (G31, aile koruyucu).

Valla onlar bana hayat veriyor, gençleştiriyor. Çok tatllar. Daha canliyım, enerjiğim (G33, aile koruyucu).

Sahanın büyükannelerin sağlığına ilişkin verileri 1şığında, torunlarına tamamlayıcı nitelikte bakım sağlamanın büyükannelerin genel sağlıkları üzerinde olumsuz bir etki yaratmadığı, aksine büyükanneleri kendilerine özen göstermeye teșvik eden, zinde ve canlı tutan bir deneyim olduğu ifade edilebilir. Üstelik bakım desteği sağlayarak çocuklarının ihtiyaçlarına cevap verebilmek, büyükannelerin psikolojik refahları üzerinde de olumlu etkilere sahiptir.

Çocuğunun rahatliğl açısından düşünüyorsun, torun sevgisi ile kendimi şey yapıyorum en azından gerçekleştiriyorum işte sevgimi, onunla bir mutluyum ama klzımın rahatladığın görünce daha mutluyum. Iş̧e yaramak güzel bir şey, zaten ebeveynlerin ben hep klzarım yani hani să̆lı̆̆l varsa bir anne-babanin kesinlikle çocuklarına özverili olması gerekir diye düşünüyorum. Yani hani ben boş bir anne baba olmayl sevmiyorum, yararın olmalı diye düşünüyorum, her şeyde ama. Elimden geldiği kadarını da sonuna kadar yaparım beğenir beğenmez o ayrı bir olay, onu da düşünmüyorum beğenilmediğini (G6, aile koruyucu).

Tamamlayıcı bakım sağlayan büyükanneler çocuk bakımı sağlamak yoluyla kendi çocuklarını mutlu edebildiklerine inanmakta, bu durum psikolojik doyumlarını artırarak bakımın bir kazanım olarak değerlendirilmesinde etkili olmaktadır.

Büyükannelerin sağlık durumlarının bakım sürecinden nasıl etkilendiğine ilişkin elde edilen veriler, özellikle Batı toplumlarında yapılmış olan çalışmaların bulgularıyla benzerlik göstermekte ve bakımının sağlandığı ailevi bağlamın sağlıkla ilintili deneyimleri farklılaştırabildiğ görüşüne katkı sunmaktadır. Torunların birincil bakım sağlayıcıları konumunda olan büyükanneler için bakım, psikolojik sağlıklarını kötüleştiren bir deneyim olmuştur. Büyük ebeveyn müdahalesini gerektiren ailevi krizlerin çocuk bakım ihtiyacı yaratmasına ek olarak bakılan torunların yaşı, cinsiyeti, sayısı gibi değişkenler de ayrıca koruyucu büyükannelerin bakım sürecini stres ile ilişkilendirmelerinde etki olmuştur. Torun bakımını psikolojik sağlıklarına olumsuz etki eden bir deneyim olarak algılama eğiliminde olan birincil bakıcı büyükannelerin aksine tamamlayıcı bir temelde bakım ağlayan büyükanneler için bakım, kazanımları oldukça yüksek olan bir sorumluluktur. Tamamlayıcı bakım sunan büyükannelerin yanı sıra kapsamlı ve düzenli bakım sunan büyükanneler de bakım sürecinin daha çok olumlu sonuçlarına odaklanma eğiliminde olmuştur. Bununla birlikte her iki aile düzenlemesinde bakım sunan büyükanneler, yoğun bir tempoda, gerilimli ilişkiler çerçevesinde ve halihazırda kötü olan sağlık koşullarında bakımı sürdürmeye devam ettiklerinde fiziksel ve psikolojik refah düzeylerinin düşebildiğini vurgulamışlardır. Düzenli ve tamamlayıcı bakımın büyükannelerin sağlık durumlarına etkisinin benzerlik göstermesinin tamamlayıcı bakımın düzenli bakımı takiben ortaya çıkmasından kaynaklandığı anlaşılmıştır. Büyükannelerin bakım faaliyetine dâhil olma dereceleriyle bağlantılı olarak sağlık durumlarına ilişkin deneyimleri farklılık gösterse de üç farklı büyük ebeveynlik modelini üstelenen büyükanneler, bakımın canlı ve enerjik olmalarının aracı olarak fiziksel sağlıkları üzerinde olumlu etki ettiği görüşünde hemfikirdir. Ayrıca, farklı niteliklerde bakım sağlayan büyükannelerin hepsinin kendi çocuklarının yardım ihtiyacına cevap vermekten du- 
yulan memnuniyet yoluyla psikolojik doyumlarının arttığı anlaşılmıştır.

\section{Sonuç}

Orta kuşakta yaşanan boşanmaların giderek yaygınlık kazanması, tek ebeveynli aile görünümünün yaygınlaşması, orta kuşaktaki kadın istihdamının artış göstermesi gibi dönüşümler, büyükannelerin torun bakım faaliyetinde daha aktif bir rol almalarında etkili olmuştur. Büyük ebeveynler, özellikle de büyükanneler çocuklarına etkili ebeveynlik yapmak konusunda zorluk yaşayan ebeveynlerin destek ihtiyacına cevap verebilmek ya da ebeveynlerin iş ve ev dengesini sağlayabilmelerine olanak sağlamak için torun bakımına giderek dâhil olmaktadırlar. Bunun yanı sıra, çalışan kadınlar için doğum sonrası ücretli/ücretsiz izin sürelerinin kısa olması, resmi çocuk bakım kurumları için mali kaynakların yetersiz olması, bu kurumların çok fazla öğrenci barındırması nedeniyle yetersiz algılanması ya da kreşe verilen paranın ailenin mali kaynaklarını boşa harcama olarak değerlendirilmesi, büyükanneleri torun bakımı konusunda en güvenilir kaynaklara dönüştürmüştür. Ancak, bakım ihtiyacını doğuran dinamiklerden hangisinin torun bakımında etkili olduğu, bakım faaliyetinin yoğunluğunu değiştirmekte, büyükannelerin aile içi konumlarına yön vermektedir. Üstelik ortalama ömrün uzaması, büyükannelerin bu rollerini daha uzun süreli olarak yerine getirmelerinde etkili olmuştur.

Araştırmaya katılan bakım sağlayıcı büyükannelerin hepsi için torun bakım faaliyeti, manevi doyum ile ilişkilidir. Zaman zaman yaşanan tüm zorluklarına rağmen, hangi ailevi bağlamda, hangi yoğunlukta sağlanırsa sağlansın bakım faaliyetinin büyükanneler için psikolojik tatmin yaratan bir araç olduğu anlaşılmıştır. Bailey ve meslektaşları (2009) da yaptıkları çalışmada büyük ebeveynler için torunlarını yetiştirmenin ödülünün maruz kalınan kaynak zorluklarının çoğunu aştığını belirlemişlerdir. Öte yandan, büyükannelerin torun bakımından kaynaklanan stres etkenlerinden ziyade torun yetiştirme duygusunun ödülüne odaklanmaları, bu göreve adapte olabilmeleri ve zorluklarıyla daha kolay başa çıkabilmeleri için önemlidir. $\mathrm{Bu}$ bakış açısı, özellikle ailevi krizlerin deneyimlendiği ailelerde bakım sağlayan büyükannelerin ailevi zorluklara aldırmayarak sonuna kadar direnmeleri için bir motivasyon oluşturabilmekte ve geleceğe umutla bakmalarına yardımcı olabilmektedir. Kendilerini daha iyi hissettiren bir şey yapmak, büyükannelerin adaptasyon süreçlerini kolaylaştıran ve depresyonla başa çıkabilmelerini sağlayan bir unsur gibi işlemektedir. Ancak nihayetinde psikolojik tatmin aracı olarak işlev gören bakım faaliyetinin büyükanneler için psikolojik ve fiziksel zorlukları olan bir sorumluluk olduğu anlaşılmıştır. Üstelik bakım yoğun ve kapsamlı bir nitelik kazandığında büyükanneler bu zorluklara karşı daha kırılgan hale gelebilmektedir. Büyükanneler için bakımın psikolojik doyum, yaşamdan duyulan memnuniyet ile fiziksel olarak canlı ve enerjik olma hali ile ilişkilendirilmesinin, tamamlayıcı nitelikte sağlanması koşulunda daha olası olduğu anlaşılmıştır. Büyükanneler, farklı gerekçelerle ortaya çıkan çocuk bakım ihtiyacına cevaben yoğun ve düzenli bakım sunmak durumunda kaldıklarında ise bakım, depresyon, stres gibi ruhsal hastalıklar ya da yorgunluk, uykusuzluk, bel ve bacak ağrıları gibi fiziksel bozukluklarla ilişkili hale gelebilmektedir. Bu nedenle büyükannelerin üstlenmiş olduğu bakım sorumluluğuna bağlı olarak deneyimledikleri sağlık sorunlarını azaltabilmek için çalışan ebeveynlerin yararlanabilecekleri kurum içi çocuk bakım hizmetlerinin yaygınlaştırılmasına ve kamu çocuk bakım kurumlarının daha ulaşılabilir hale getirilmesine ihtiyaç vardır. Bu düzenleme, özellikle düzenli ve yoğun nitelikte bakım sağlayan büyükannelerin bakım yüklerini azaltarak torunlarıyla daha keyifli ve kendi istekleri doğrultusunda zaman geçirmelerini mümkün kılabilecektir.

Yazarın Notu: Bu çalışma, Prof. Dr. Nurşen Adak danışmanlığında yürütülen "Büyük Ebeveyn ve Torun İlişkileri: Çocuk Bakım Pratikleri Üzerine Bir Araştırma" başlıklı doktora tezinden üretilmiştir. 


\section{KAYNAKÇA}

Adak N. (2017). "Toplumun Temel Yapı Taş1: Aile”. Ed. Sevinç Güçlü. Kurumlara Sosyolojik Bakış (2017) 27-63. İstanbul.

Akın G. (2006). Her Yönüyle Yaşlılık. Ankara 2006.

Armstrong M. J. (2005). "Grandchildren's Influences on Grandparents: A Resource for Integration of Older People in New Zealand's Aging Society". Journal of Intergenerational Relationships 3/2 (2005) 7-21.

Bailey S. J., Letiecq B. L. \& Porterfield F. (2009). "Family Coping and Adaptation Among Grandparents Rearing Grandchildren". Journal of Intergenerational Relationships 7/2 (2009) 144-158.

Barnett M. A., Scaramella L. V., Neppl T. K., Ontai L. L. \& Conger R. D. (2010). "Intergenerational Relationship Quality, Gender and Grandparent Involvement". Fam Relat 59/1 (2010) 28-44.

Bates J. S. (2009). "Generative Grandfathering: A Conceptual Framework for Nurturing Grandchildren". Marriage \& Family Review 45/4 (2009) 331-352.

Bowers B. F. \& Myers B. J. (1999). "Grandmothers Providing Care for Grandchildren: Consequences of Various Levels of Caregiving”. Family Relations 48/3 (1999) 303-311.

Breheny M., Stephens C. \& Spilsbury L. (2013). "Involvement without Interference: How Grandparents Negotiate Intergenerational Expectations in Relationships with Grandchildren". Journal of Family Studies 19/2 (2013) 174-184.

Bundy-Fazioli K., Fruhauf C. A. \& Miller C. L. (2013). "Grandparents Caregivers' Perceptions of Emotional Distress and Well-Being". Journal of Family Social Work 16/5 (2013) 447-462.

Choi M., Sprang G. \& Eslinger J. G. (2016). "Grandparents Raising Grandchildren: A Synthetic Review and Theoretical Model for Interventions". Family and Community Health 39/2 (2016) 120-128.

Clarke L. \& Roberts C. (2003). "The Meaning of Grandparenthood and its Contribution to the Quality of Life of Older People". Ed. A. Walker \& C. H. Hennessy, Growing Older: Quality of Life in Old AgeIts Meaning and its Contribution to Older People's Lives (2003) 188-208. England.

Cox C. (2008). "Empowerment as an Intervention with Grandparent Caregivers". Journal of Intergenerational Relationships 6/4 (2008) 465-477.

Danielsbacka M., Tanskanen A. O. \& Rotkirch A. (2015). "Impact of Genetic Relatedness and Emotional Closeness on Intergenerational Relations". Journal of Marriage and Family 77/4 (2015) 889-907.

Dellmann-Jenkins M., Hollis A. H. \& Gordon K. L. (2005). "An Intergenerational Perspective on Grandparent Roles: Views of Young Parents and Middle-Age/Older Adults". Journal of Intergenerational Relationships 3/1 (2005) 35-48.

Denham T. E. \& Smith C. W. (1989). "The Influence of Grandparents on Grandchildren: A Review of the Literature and Resources". Family Relations 38/3 (1989) 345-350.

Doley R., Bell R. R., Watt B. \& Simpson H. (2015). "Grandparents Raising Grandchildren: Investigating Factors Associated with Distress Among Custodial Grandparent". Journal of Family Studies 21/2 (2015) 101-119.

Erbert L. A. \& Aleman M. W. (2008). "Taking the Grand out of Grandparent: Dialectical Tensions in Grandparent Perceptions of Surrogate Parenting”. Journal of Social \& Personal Relationships 25/4 (2008) 671-695.

Gauthier A. (2002). “The Role Of Grandparents”. Current Sociology 50/2 (2002) 295-307.

"Geçmişe Bir Gülücük Çek". Theraphysio, 4. Sayı (1 Ekim Dünya Yaşlılar Günü Özel Sayı). Kaynak: https://issuu.com/theraphysio/docs/theraphysio4.say

Goodman C. C. \& Silverstein M. (2001). "Grandmothers Who Parent Their Grandchildren: An Exploratory Study of Close Relations Across Three Generations". Journal of Family Issues 22/5 (2001) 557-578.

Griggs J., Tan J., Buchanan A., Attar-Schwartz S. \& Flouri E. (2010). "They've Always Been There for Me': Grandparental Involvement and Child Well-being”. Children \& Society 24/3 (2010) 200-214.

Haviland W. A., Prins H. E. L., Walrath D. \& McBride B. (2008). Kültürel Antropoloji. Çev. İ. D. Erguvan Sarıoğlu. İstanbul 2008. 
Hayslip B. Jr. \& Goodman C. C. (2008). "Grandparents Raising Grandchildren: Benefits and Drawbacks?". Journal of Intergenerational Relationships 5/7 (2008) 117-119.

Herlofson K. \& Hagestad G. O. (2012). "Transformations in the Role of Grandparents Across Welfare States". Ed. Sara Arber \& Virpi Timonen. Contemporary Grandparenting: Changing Family Relationships in Global Contexts (2012) 27-49. Bristol.

Kemp C. L. (2007). "Grandparent - Grandchild Ties. Reflections on Continuity and Change Across Three Generations”. Journal of Family Issues 28/7 (2007) 855-881.

Kümbetoğlu B. (2017). Sosyolojide ve Antropolojide Niteliksel Yöntem ve Araştırma. İstanbul 2007.

Macionis J. (2012). Sosyoloji. Ankara 2012.

Margolis R. (2016). "The Changing Demography of Grandparenthood". Journal of Marriage and Family 78 (2016) 610-622.

Mehta K. K. \& Thang L. L. (2012). "Introduction: Grandparenthood in Asia”. Ed. K. K. Mehta \& L. L. Thang, Experiencing Grandparenthood An Asian Perspective (2016) 1-19. New York.

Richard A. \& Harris P. (2001). “Second Time Around': A Survey of Grandparents Raising Their Grandchildren". Adoption and Fostering 25/3 (2001) 67-69.

Sennett R. (2014). Karakter Aşınması. İstanbul 2014.

Timonen V. \& Arber S. (2012). “A New Look at Grandparenting”. Ed. Sara Arber \& Virpi Timonen, Contemporary Grandparenting: Changing Family Relationships in Global Contexts (2012) 1-24. Bristol.

Villar F., Triado C., Pinazo-Hernandis S., Celdran M. \& Sole C. (2010). "Grandparents and Their Adolescent Grandchildren: Generational Stake or Generational Complaint? A Study with Dyads in Spain". Journal of Intergenerational Relationships 8/3 (2010) 281-297.

Wang Y. \& Marcotte D. E. (2007). "Golden Years? The Labor Market Effects of Caring for Grandchildren”. Discussion Paper Series IZA DP No. 2629 (2007) 1-38.

Werner P., Buchbinder E., Lowenstein A. \& Livni T. (2007). “Grandmothers', Mothers' and Granddaughters' Perceptions of Grandparenthood”. Journal of Intergenerational Relationships 5/3 (2007) 7-26.

Westphal S. K., Poortman A. \& Van der Lippe T. (2015). "What About the Grandparents? Children's Postdivorce Residence Arrangements and Contact with Grandparents". Journal of Marriage and Family 77/2 (2015) 424-440.

Williams M. N. (2011). “The Changing Roles of Grandparents Raising Grandchildren”. Journal of Human Behavior in the Social Environment 21/8 (2011) 948-962.

Williamson J., Softas-Nall B. \& Miller J. (2003). "Grandmothers Raising Grandchildren: An Exploration of Their Experiences and Emotions". Family Journal 11/1 (2003) 23-32.

Wood S. \& Liossis P. (2007). "Potentially Stressful Life Events and Emotional Closeness Between Grandparents and Adult Grandchildren". Journal of Family Issues 28/3 (2007) 380-398.

Worrall J. (2007). "Grandparent Custody of Children at Risk: Counting the Cost". Journal of Intergenerational Relationships 5/3 (2007) 127-130.

Worrall J. (2009). "When Grandparents Take Custody - Changing Intergenerational Relationships: The New Zealand Experience”. Journal of Intergenerational Relationships 7/2-3 (2009) 259-273 
